\title{
TUMOR SUPRESOR GEN p53 SEBAGAI TARGET PENGOBATAN "CANCER"
}

\author{
Jekson Martiar Siahaan ${ }^{\bowtie}$, Tengku Muhammad Fauzi \\ Fakultas Kedokteran, Universitas Methodist Indonesia, Medan, Indonesia \\ Email: jekson.siahaan.sked@gmail.com
}

DOI: https://doi.org/10.46880/methoda.Vol11No1.pp10-13

\begin{abstract}
The 53 protein functions as a biological molecule that breaks the cycle of damage to DNA damage, even the important function of this molecule is to check whether the organ cells are complete or damaged. However, p53 can undergo mutations that will instead be oncogene. One way to deal with this is gene therapy, namely PRIMA-1 (p53 Reactivation and Induction of Massive Apoptosis). Until now, further studies are still needed on the effectiveness of this therapy
\end{abstract}

Keyword: p53, Oncogene, PRIMA-1 (p53 Reactivation and Induction of Massive Apoptosis)

\section{PENDAHULUAN}

Tumor Supresor gen p53 merupakan molekul biologi yang penting dalam tubuh manusia sebagai penjaga integritas genom, dan memastikan homeostasis sel berjalan dengan baik (Foulkes, 2007; Teoh \& Chng, 2014). Lane pada tahun 1992 menyebutnya sebagai penjaga genom karena mencegah mutasi sel sedangkan levine pada tahun 1997 menjulukinya sebagai penjaga gerbang sel (Zilfou dan Lowe, 2009; Stojnev et al., 2010). Protein p53 (p53) berperan sebagai tumor supresor disandi oleh gen p53 (p53) terletak pada lengan pendek kromosom 17p13.1dan tersusun dari 393 asam amino (Wei et al., 2012; Stojnev et al., 2010).

Fungsi biologis protein p53 sebagai faktor transkripsi multitarget gen, regulasi siklus sel, penuaan sel, apoptosis, sintesis DNA, perbaikan kerusakan DNA yang diakibatkan bahan genotoksik, angiogenesis dan stress oksidatif (Foulkes, 2007; Vinyals et al., 1999). Protein ini berperan penting dalam mencegah tumor dengan menghentikan siklus sel atau memprogram kematian sel sebagai respon kerusakan DNA (Silva et al., 2013)

Kerusakan DNA diatasi p53 dengan mengistirahatkan siklus sel dan apotosis namun apabila terjadi mutasi p53 maka bukan tidak mungkin si "penjaga genom" menjadi onkogen. Mutasi ini sering ditemukan pada kanker, diakibatkan oleh kerusakan DNA sehingga fungsi antiproliferasi sel seperti apoptosis dan penuaan sel tidak terjadi (Stojnev et al., 2010). Protein p53 meskipun bukan antigen spesifik kanker namun peran sebagai kontrol pertumbuhan sel, apoptosis dan seringnya mengalami mutasi dapat dijadikan target terapi pada penderita kanker (Stokłosa dan Gołạb, 2005)

\section{PEMBAHASAN}

\section{Sejarah Penemuan p53}

Penelitian awal protein p53 dimulai pada tahun 1979 dalam bentuk protein selular 53- $k D a$ yang terikat antigen $\mathrm{T}$ besar pada virus DNA SV40 (Harris, 1996). Awalnya para peneliti belum memikirkan p53 sebagai 
penyebab kanker, pada tahun 1977 para peneliti masih beramsumsi bahwa kanker disebabkan oleh virus namun pada 1980, Michel Kress menemukan bahwa virus bukanlah penyandi sel kanker namun sel pejamu itu sendiri, hal ini senada dengan penelitian - penelitian p53 oleh Kress et al, 1979; Lane \& Crawford, 1979; Linzer \& Levine, 1979 (Soussi, 2010). Sejarah penelitian p53 dapat dijelaskan pada gambar 1.

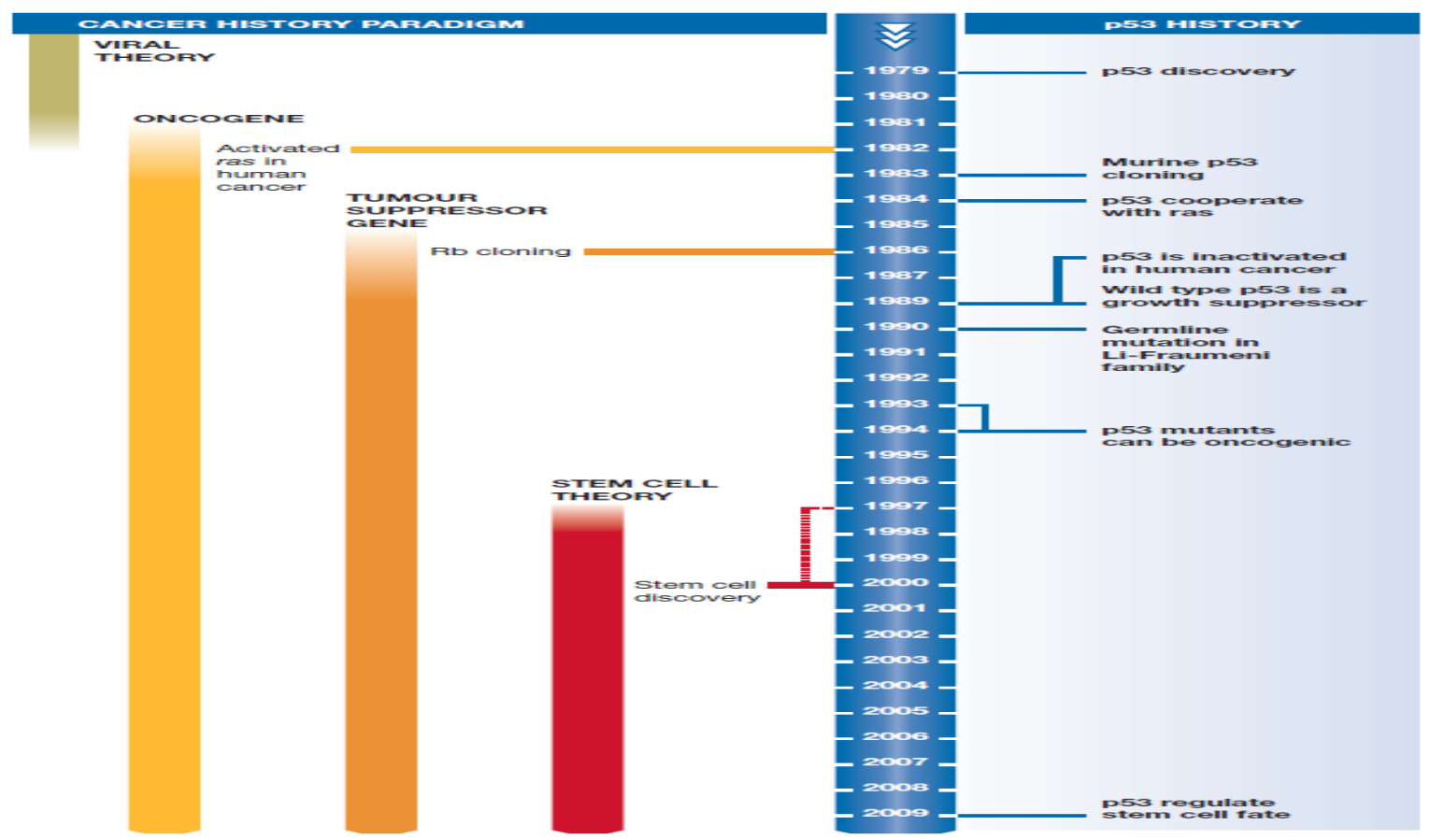

Sumber: (Soussi, 2010)

Gambar 1. Sejarah Penelitian p53

\section{Struktur p53}

Protein p53 (p53) merupakan tetrameric nuclear phosphoprotein, terletak pada lengan pendek kromosom 17p13.1, berperan penting pada patogenesis kanker (Silva et al., 2013; Teoh \& Chng, 2014). p53 pada manusia terdiri dari 393 asam amino dan memiliki 3 domain utama:

\section{N-Terminal transcription-activation} domain (TAD), yang berfungsi mengaktivasi faktor-faktor transkripsi, yaitu pada residu 1-42 dan untuk berinteraksi dengan berbagai macam protein.

II. CTD (C-terminal domain), berfungsi untuk tetramerisasi.

III. Core domain (p53C), terletak pada residu 94-312 yng menyusun sequencespecific DBD (DNA-binding region)
(Silva et al., 2013).

\section{Fungsi p53}

Protein p53 akan teraktivasi apabila ada kerusakan DNA, single stranded DNA, stres oksidatif, shock osmotik, deplesi ribonukleat dan berbagai bentuk distress sel. Fungsi p53 sebagai tumor supresor gen melalui multiple mekanisme yakni:

I. Mengaktifkan reparasi DNA setelah kerusakan DNA.

II. Menghentikan siklus sel melalui mekanisme cek Siklus G1/S saat reparasi DNA.

III. Menginisiasi kematian sel terprogram, pada saat terjadi kerusakan DNA (Stojnev et al., 2010).

Peran p53 dalam cek poin siklus sel yakni mengkontrol pembelahan sel apakah 
komponen sel sudah lengkap untuk dilanjutkan ke fase berikutnya (Zilfou dan Lowe, 2009). Ketika sel mengalami distress maka p53 akan teraktivasi untuk mencegah proliferasi yang tidak terkendali, peran sentral p53 dapat dijelaskan pada gambar 2 berikut ini:

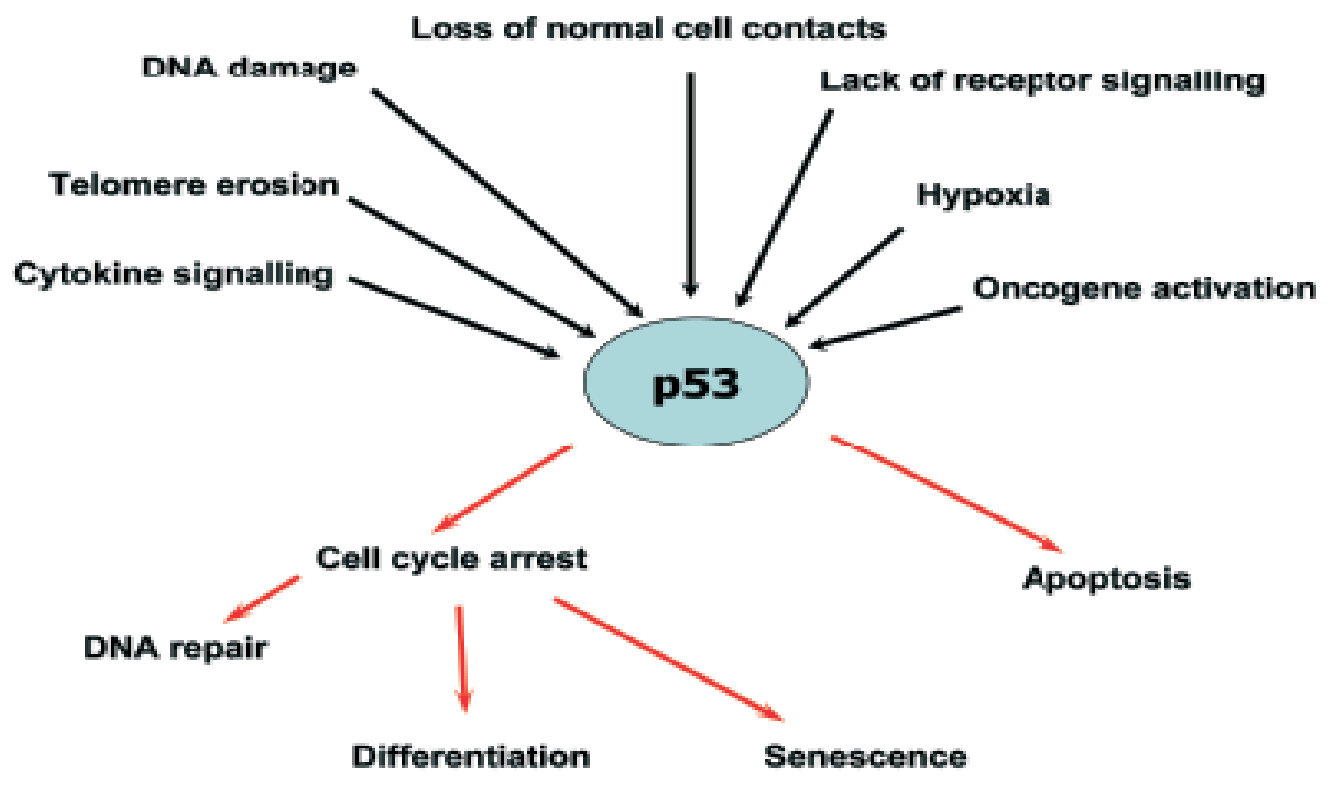

Sumber: (Stokłosa \& Gołạb, 2005)

Gambar 2. Fungsi p53

\section{Mutasi p53}

Mutasi p53 berperan penting dalam perkembangan kanker p53 yang nonaktif menyebabkan hampir 50\% kanker pada manusia (Silva et al., 2013). Mutasi gen p53 ditemukan pada lesi prakanker terutama bila terpapar bahan karsinogen. Mutasi p53 bukanlah hal yang penting dalam menginisiasi karsinogenesis namun mutasi protein tersebut meniadakan sinyal apoptosis dan mengistirahatkan siklus sel (Stojnev et al., 2010). Berikut tabel 1 menjelaskan mutasi p53 pada kanker manusia

\begin{tabular}{|c|c|c|}
\hline \multirow[t]{2}{*}{ Protein } & Cancer type & Number of cases \\
\hline & Breast cancer & \\
\hline \multirow[t]{6}{*}{ p53 } & $\begin{array}{l}\text { (i) } p 53 \beta \text { was detected in } 36 \% \text { breast tumors and associated with the } \\
\text { expression of estrogen receptor (ER). }\end{array}$ & \multirow{3}{*}{127 breast tumors } \\
\hline & $\begin{array}{l}\text { (ii) p53y was detected in } 37 \% \text { breast tumors and associated with } \\
\text { mutations in the } 553 \text { gene. }\end{array}$ & \\
\hline & $\begin{array}{l}\text { (iii) Patients with mutant } \mathrm{p} 53 \text { and } \mathrm{p} 53 \gamma \text { isoform had a low cancer } \\
\text { recurrence and an overall survival as good as that of patients with wild } \\
\text { type p } 53 \text {. }\end{array}$ & \\
\hline & $\begin{array}{l}\text { (i) } \mathrm{p} 53 \text {, p } 53 \beta \text {, and } \mathrm{p} 53 \gamma \mathrm{mRNA} \text {, but not transcripts for } \Delta 133 \mathrm{p} 53 \alpha \text {, } \\
\Delta 133 \mathrm{p} 53 \beta \mathrm{mRNA} \text {, and } \Delta 133 \mathrm{p} 53 \gamma \text {, were detected in normal breast } \\
\text { tissues. }\end{array}$ & \multirow{3}{*}{$\begin{array}{l}30 \text { breast tumors and } 8 \text { norma } \\
\text { breast samples }\end{array}$} \\
\hline & $\begin{array}{l}\text { (ii) } \mathrm{p} 53 \beta \mathrm{mRNA} \text { was detected in } 10 / 30 \text { tumors; } \Delta 133 \mathrm{p} 53 \alpha \text { mRNA was } \\
\text { detected in } 24 / 30 \text { tumors; } 533 \gamma, \Delta 133 \mathrm{p} 53 \beta \text {, and } \Delta 133 \mathrm{p} 53 \gamma \text { were } \\
\text { undetected in tumors. }\end{array}$ & \\
\hline & (iii) Some tumors can express mutant p53 but wild type $\Delta 133 p 53$. & \\
\hline
\end{tabular}

Sumber: (Wei et al., 2012)

Tabel 1. Mutasi p53 Pada Kanker Manusia 


\section{Strategi Teraupetik}

Mutasi p53 memicu terjadinya kanker sehingga para ahli mulai memikirkan strategi teraupetik yang tepat yakni melalui gene terapi, salah satunya adalah PRIMA-1 (p53 Reactivation and Induction of Massive Apoptosis). PRIMA-1 merupakan molekul kecil yang memicu apoptosis masive sel kanker, namun PRIMA-1 masih menjadi suatu pertanyaan mengapa sel kanker tanpa p53 dapat mengalami apoptosis, sehingga masih diperlukan adanya studi rinci agar dapat mengaplikasikan PRIMA-1 dalam pengobatan (Stokłosa dan Gołąb , 2005; Teoh \& Chng 2014).

\section{PENUTUP}

P53 merupakan tumor supresor gen yang berperan sebagai penjaga genom, namun disfungsi dapat terjadi bila sel mengalami distress bahkan dapat menjadi mutasi dan berakibat terjadinya kanker. Pentingnya pengetahuan tentang p53 memungkinkan untuk mengali lebih luas potensi sebagai gene terapi.

\section{DAFTAR PUSTAKA}

Foulkes, W. D. (2007). p53 - Master and Commander. New England Journal of Medicine, 357(25), 2539-2541. https://doi.org/10.1056/NEJMp070742 2

Harris, C. C. (1996). p53 Tumor suppressor gene: from the basic research laboratory to the clinic - an abridged historical perspective. Carcinogenesis, 17(6), 1187-1198. https://doi.org/10.1093/carcin/17.6.118 7

Silva, J. L., Rangel, L. P., Costa, D. C. F., Cordeiro, Y., \& De Moura Gallo, C. V. (2013). Expanding the prion concept to cancer biology: dominantnegative effect of aggregates of mutant p53 tumour suppressor. Bioscience Reports, 33(4), 593-603. https://doi.org/10.1042/BSR20130065
Soussi, T. (2010). The history of p53. EMBO Reports, 11(11), 822-826. https://doi.org/10.1038/embor.2010.15 9

Stojnev, S., Golubović, M., \& Babović, P. (2010). TP53 gene mutations-from guardian of the genome to oncogene. Acta Medica Medianae, 48(4):59-6.

Stokłosa, T., \& Gołąb, J. (2005). Prospects for p53-based cancer therapy. Acta Biochimica Polonica, 52(2), 321-328.

Teoh, P. J., \& Chng, W. J. (2014). p53 Abnormalities and Potential Therapeutic Targeting in Multiple Myeloma. BioMed Research International, 2014, 1-9. https://doi.org/10.1155/2014/717919

Vinyals, A., Peinado, M. A., GonzalezGarrigues, M., Monzo, M., Bonfil, R. D., \& Fabra, A. (1999). Failure of wild-type p53 gene therapy in human cancer cells expressing a mutant $\mathrm{p} 53$ protein. Gene Therapy, 6(1), 22-33.

Wei, J., Zaika, E., \& Zaika, A. (2012). P53 family: Role of protein isoforms in human cancer. Journal of Nucleic Acids, 2012(January). https://doi.org/10.1155/2012/687359

Zilfou, J. T., \& Lowe, S. W. (2009). Tumor suppressive functions of p53. Cold Spring Harbor Perspectives in Biology, 1(5), 1-12. https://doi.org/10.1101/cshperspect.a0 01883 